\title{
HISTORICAL AND MODERN APPROACH TO THE ISSUE OF WOMEN AND SOCIETY: ANALYZE TWO NOVELS
}

CAbdirashidov Z., ORCID: 0000-0002-6869-4315, M-7835-2015, Dr. of Philosophy, Tashkent State University of the Uzbek Language and Literature, Tashkent,Uzbekistan, sarvahon@mail.ru

CSotiboldiyeva R., ORCID: 0000-0002-0076-6685, Dr. of Science, Tashkent State University of the Uzbek Language and Literature, Tashkent,Uzbekistan, sarvahon@mail.ru

\section{ИСТОРИЧЕСКИЙ И СОВРЕМЕННЫЙ ПОДХОД К ВОПРОСУ ЖЕНЩИН И ОБЩЕСТВА: АНАЛИЗ ДВУХ ПРОИЗВЕДЕНИЙ}

(C)Абдирашидов 3. ШI., ORCID: 0000-0002-6869-4315, M-7835-2015, Dr. of Philosophy,

Ташкентский государственный университет узбекского языка и литературы им. Алишера Навои, г. Ташкент, Узбекистан, sarvahon@mail.ru

(С)Соиболдиева C. P., ORCID: 0000-0002-0076-6685, Dr. of Science,

Ташкентский государственный университет узбекского языка и литературы им. Алишера Навои, г. Ташкент, Узбекистан, sarvahon@mail.ru

Abstract. This article is devoted to the urgent problem of women and society at all times. As in many areas, this issue is also one of the main objects of literature. The purpose of the article is the place of women of the East in society and the study of the reflection of this issue in fiction and a comparative interpretation of their common and distinctive features. The article also covers and analyzes the views of outstanding educators - the scientist Ismail Gasprinsky and the famous Iranian writer Shahrnush Porsipur about a woman and her place in society and family, her duties and rights.

Аннотащия. Данная статья посвящается актуальной во все времена проблеме женщины и общества. Во многих сферах этот вопрос также является одним из основных объектов литературы. Цель статьи: место женщин Востока в обществе и изучение отражения этого вопроса в художественной литературе, сравнительная интерпретация их общих и отличительных черт. Статья также охватывает и анализирует взгляды выдающихся просветителей: ученого Исмаила Гаспринского и известной иранской писательницы Шахрнуш Порсипур о женщине и ее месте в обществе и семье, ее обязанностях и правах.

Keywords: women of the East, Ismail Gasprinsky, Shahrnush Porsipur, feminism.

Ключевые слова: женщина Востока, Исмаил Гаспринский, Шахрнуш Порсипур, феминизм. 


\section{Introduction}

The way of portraying the dream society in the example of a hypothetical country, the way of setting place of plot has existed in the works of writers, poets and scholars since ancient times. One of the most famous works of this method is the work of the great thinker Abu Nasr Farabi, "Fozil Shahar Aholisi Maslagi" (The Goal of a Fair City People), the novel of "The Muslims of DoruRohat" by Ismail Gasprinsky, a Crimean Tatar educator and one of the founders of the Jadid movement. This method is used for various reasons and consequences of different situations. These include the crackdown on creative freedom, the strong pressure on literature, the alienation from society, the discrimination of human rights, the writer's creative intent, the ideas he proposes and many other reasons. For example, Farabi's ideas about a vibrant society, a perfect man, a wise leader, equality, mutual understanding, cooperation, and a unique human community were totally alien to his time. The thinker has only dreamed about it and creates the image of a utopian city with dreams. Ismail Gasprinsky also tells the story of a mysterious country called Rohat, whose culture, science and craftsmanship advanced beyond the borders of the world. The author draws the reader into the realm of artistic fantasy based on events from ancient times. Gasprinsky attempts to expose the state of the Muslim world through the events of Europe and the Caliphate of Andalusia by means of changing setting, especially the place [1].

\section{Material and research methods}

Through the imaginative 'territory', one can see the widespread use of literary works by writers of different nationalities to describe the destiny of women, their problems, and their hopes. The proof of our opinion can be seen in the example works by a world-recognized author with a title of "Ustozi Muazzam" (the Great Teacher) Ismail Gasprinsky [2] that his fantasy-adventure story "The Land of Ladies" and a famous Persian writer Sharhnush Porsipur [3] whose works has been translated into many languages and being recognized and one of her novels "Ladies Without Gentlemen".

The research was conducted based on comparing and analyzing methods for this article.

\section{Results and discussion}

One of the issues that had to be addressed before society in the late 19th and early 20th centuries, during the Renaissance in the Muslim Orient, was to make women active members of society, to educate and literate them. Ismail Gasprinsky, one of the founders and active practitioners of the Jadid movement among Russian Muslims, began to address the issue of women, their role in society, and their role in the upbringing of the future generation from the 1880s. In particular, one of the main lines of the "Tarjimon" (Translator) newspaper was the issue of Muslim women. He also worked hard to produce separate editions for women in 1887 and 1891 . However, due to the opposition of the Russian Empire government officials, he could not fulfill his purpose [2]. Only in 1906, Gasprinsky obtained permission to publish a newspaper under the name "Olami Nisvon" (World of Women), and he appointed his eldest daughter Shafiqa as an editor for the press.

In his articles, Gasprinsky frequently cites the example of Muslim woman's insecurity in society, their inability to apply to the Shari'a courts to defend their rights in the light of family injustice. These issues can be clearly seen in his works. Gasprinsky's novels and stories such as "Muslims of Doru-Rohat", "Letters of France", "Letters of Sudan", "The Land of Women" show how serious he looked at the actual role of Muslim women in the society and how he approached the issue of women. Ismail Gasprinsky in the work "Muslims of Doru-Rohat" created the image of 
a female judge who could deal with family matters along with male judges of the same function. No family dispute can be resolved without the consent of the female judge, and the decisions made are not legally binding. In the story of "The Land of Women", Gasprinsky changes the positions of male and female in society and depicts the former as inferior to the later. In the country of women created in this work, a man has to cover his face, educate children, cook meals and do housework. In short, the man in that country was in the position of woman, unlike our society. This way, Gasprinsky raised the issue of the true role of Muslim woman in society and put the issue to public discussion. In "The Land of Ladies" a group of tourists from different countries (Arab, Sudanese, French) and various professions (pilgrims, servants, doctors, engineers), who had started travelling from Algeria, lost their way during their journey and visit "The Land of Ladies" by chance and the plot is built on their adventures in the land. The first aspect that attracts the reader to the work is 'worrying' words of the male travelers about the land of ladies even at the beginning of foreword of the novel: "Abbos Afandi, could you ask from caravan leader if we have already passed from "The Land of Ladies"? May we not come across their land by chance ...", "Come on, Brother! Don't dare to say something like that! The women of that land are not like the ones that you know... The women are at warfare and fighting while their husbands are at home doing house chores including cooking and doing washing. In short, the men are in the position of women in our society... May God bless us". The way the author uses to begin the novel grabs the attention of reader. The thought that emerged in this dialogue is a prelude to a masterpiece: the main idea is that the destiny of women who have become victims of community and heresy should be experienced by men in their bodies as well. In this country, "the men are not liberated, they are taken to harem, they are seen as a lady love", "they are brutally stared at", "they live their lives barely, cover their faces with veils", the male servants' faces are "covered in makeup powder as French prostitutes, their eyes are colored, their mustache is lubricated", as each women have "two or three slave husbands, one is responsible for bringing children up, another is busy by cooking, milking the cow, the other does threading and sewing" and so on. In short, every kind of humiliation done upon women is done on men here; all power is in the hands of women. The 'worry' at the beginning of the novel is clarified here.

Through this illustration Gasprinsky clearly points out the position, status of Muslim women in the society of that time. It is not by accident that the author introduces the characters of French cannoneer Marten and the physician Can. By expressing their opinions, the comparisons of Turkish and French women are drawn and the idea of how responsible the women are in the society is illuminated. The following quote from French Marten says: "My friends! As you know, we are going to act like as shy as a girl, as obedient as a Muslim woman, and do heavy makeup as a French lady. Here we learn how to sew and patterns which are appropriate for men to do ... We have arrived in the best land... However, do not panic, we should learn from our current situation. We are going to experience and realize the situations, feelings, experiences of women in our lands. We are going to learn our such lesson that is neither taught at a madrasah in Tashkent nor at a French university ..." [4, p. 138].

Similarly, the author emphasizes the fact that in Islam, women are protected by the Shari'ah, and how greatly they are respected. This means that those who are literal ignorant act in any way, that they are neither influenced by laws of Shari'ah nor by the laws of society.

Another work that is devoted to the destiny of women is "مردان بدون زنان" (Women Without Husbands, 1989) by a Persian writer Shahrnush Porsipur in which she puts their destiny in paper in a unique literary way. The character of a heroine who rebelled against laws which influence the destiny of women in the society she lives is created. Some foreign researchers consider the author to be a propagandist of feminism. However, it is difficult to agree with this viewpoint. 
The way women behave, the way they upraise, rebel when necessary in front of men is completely different from what is known as feminism in Western culture. Our long year researches into the lifestyle of Iran through scientific literature, the works of female authors and conversations with people from Iran has proved that there has never been any upraise of women to claim equal rights or more rights than men in Iran. They just want the women to stay as women and want to have rights only appropriate for women (such as the right of motherhood, to marry the person they want, participating in socio-political life of the country). The case of three out of five women finding their partners and marrying them happily ever after at the end of the novel of "Women without husbands" by Shahrnush is also the proof of our idea.

The main characters in the novel are mainly women that chapters of the novel are named after those women accordingly: مهذخت (Mahduht), فائزه (Foyze), زرين كلاه (Zarrinkuloh), مونس (Munis), فرخ لقا (Farrukhliko). Those five women have their own way of destiny. These ways cross one another at one destination - at the GARDEN created by Farrukhliko. The women abandon their houses to express their dissatisfaction from the lifestyle and events they are going through. They are sexually abused (Foyze), cheated by their relatives or people they trusted most (Mahduht), forced to lead the life of a prostitute, faced brutal challenges (Zarrinkuloh), and the last one is a woman teacher who had restricted herself from all beautiful sides of life (Munis).

The novel includes the characters of Garden and "The People of Garden" which is the symbol of pure love, faithful and warm relations dreamt by the Porsipur. The garden is created in the area of Karaj outside Tehran that the women establish the society they dreamt of there. The novel includes multi chapters and each chapter is devoted to the destiny of a single character/heroine mentioned above. The same garden houses the change of myth and reality. For instance, one of the heroines of the novel, Mahduht, announces herself to be a "tree" in the garden and promises not to produce "pure fruits" unless she has close relations and for those relations she requires her feet to be "planted" in the soil. And she produces her own flowers. The tree that Mahduht turns into symbolizes womanhood and love without wild lust in the viewpoint of Porsipur. Each tree and flower in the garden have a position of a real human being in an unnatural and bizarre way. The last chapters of the work clearly point out the last words about each character of the novel. In order to make it more accurate and to have vivid imagination, we are going to provide an example. This is the conclusion of Zarrinkuloh that her life also ends in a bizarre way:

زرين كلاه با باغبان مهربان ازدو اج كرد. حامله شد. يك نيلوفر زاييد.بجه اش دوست داشت و حوضجهُ كوجه كنار

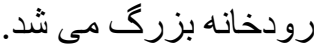

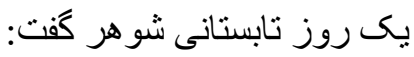

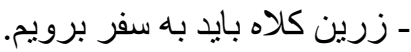

Zarrinkuloh married to a Kind gardener. She got pregnant. She gave a birth to a water lily. She loved her daughter infinitively and raised her by a lake. One day her husband said:

— Zarrinkuloh, we need to start a journey [4, p. 138].

Then Zarrinkuloh begins to get ready for the journey and starts to pack her clothes and her husband informs that "We won't need any clothes" [4, p.139], which make the case even more mysterious. Husband and wife sit on the petals of water lily. The water lily wraps them tightly with her petals and takes them away to the heaven [4, p. 139].

Munis also travels into the heaven turning into light, a black wind takes her to the heaven, and she returns a city after seven years. She wears neat clothes and turns into an ordinary schoolteacher [4, p. 136]. 


\section{Conclusions}

The message of the novel is to sing the song of a pure love which is free from any kind of cruelty and wild lust. At the same time, the destiny of women in the novel point out how dark spots the political events in Iran in 1953 left for women. The novel has been translated into English, French and German and a world-famous artist and a movie director Shirin Neshot made a film under the title of "The Summer of 1953" (in the year of 2008).

Although the events in novel was described exaggeratedly, the moral of the story Although the events of the plot moves in a way 'high' surrealism, the main message of the novel is devoted to the issues of attitude towards women, serious behavioral problems related to women, disrespect towards women in most cases and dignity and honor of women in Iran [5].

The works of Gasprinsky and Porsipur do not only share the way of using the same technique in literature which is the change of setting into 'an imaginary land', but they both also come up with the same idea about the position of women in the society. The unique feature of the work by Gasprinsky is sarcastic attitude; critical thinking about the position of women and his sarcastic expression of the issue while the work of Porsipur is dominated mainly by a tragic pathos. The work of Gasprinsky "The Land of Ladies" which is an adventure story emphasizes didactics and behavioral aspects. However, both works are worth attention since they end with an optimistic spirit.

\section{References:}

1. Gasprinsky I. (2013). Farog'at o'lkasi [The land of joy]. Tashkent, Muharrir, (Responsible editor, the responsible person for preparing the work to publishing and the author of foreword is $\mathrm{Z}$. Abdirashidov), 4-8. (in Uzbek).

2. Abdirashidov, Z. (2011). Ismoilbek suygan ayollar [Women loved by Ismoilbek]. Tafakkur, (4), 63. (in Uzbek).

3. Abdirashidov, Z. (2012). Ustozi Muazzam [The Great Teacher]. World literature, (6), 156164. (in Uzbek).

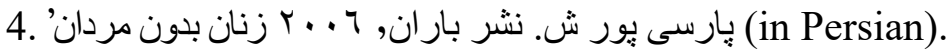

5. Abdirashidov, Z. (2017). Gasprinsky (Gaspirali), Ismail. Encyclopaedia of Islam, THREE. Edited by: Kate Fleet, Gudrun Krämer, Denis Matringe, John Nawas, Everett Rowson. Consulted online on, 16, 2015-3.

\section{Список литературы:}

1. Gaspirinsky I. Farog'at o'lkasi. Tashkent: Muharrir, 2013. S. 4-8. (на узб. яз.).

2. Abdirashidov Z. Ismoilbek suygan ayollar // Tafakkur. 2011. №4. S. 63. (на узб. яз.).

3. Abdirashidov Z. Ustozi Muazzam // World literature. 2012. №6 (181), S. 156-164. (на узб. яз.).

4. بارسى يُور ش. نشر بار ان, 7 . . . ز زنان بدون مردان (на фарси).

5. Abdirashidov Z. Gasprinski Gaspirali, Ismail // Encyclopaedia of Islam, THREE. Edited by: Kate Fleet, Gudrun Krämer, Denis Matringe, John Nawas, Everett Rowson. 2017. V. 16. P. 2015-3. 
Ссылка для цичтирования:

Abdirashidov Z., Sotiboldiyeva R. Historical and Modern Approach to the Issue of Women and Society: Analyze Two Novels // Бюллетень науки и практики. 2019. Т. 5. №10. С. 311-316. https://doi.org/10.33619/2414-2948/47/37

Cite as (APA):

Abdirashidov, Z., Sotiboldiyeva, R. (2019). Historical and Modern Approach to the Issue of Women and Society: Analyze Two Novels. Bulletin of Science and Practice, 5(10), 311-316. https://doi.org/10.33619/2414-2948/47/37 (in Russian). 